\title{
SISTEM INFORMASI BENCANA TANAH LONGSOR (SI-BENAR) BERBASIS WEB KECAMATAN CILILIN, KABUPATEN BANDUNG BARAT
}

\section{WEB-BASED LANDSLIDE DISASTER INFORMATION SYSTEM APPLICATION (SI-BENAR) CILILIN DISTRICT, WEST BANDUNG REGENCY}

\author{
Bondan Fiqi Riyalda ${ }^{1}$, Iyan Turyana ${ }^{2}$ dan Eko Widi Santoso ${ }^{2}$ \\ ${ }^{1}$ Perekayasa Pertama pada Pusat Teknologi Reduksi Risiko Bencana (PTRRB) - BPPT. \\ ${ }^{2}$ Perekayasa Madya pada Pusat Teknologi Reduksi Risiko Bencana (PTRRB) - BPPT. \\ Gedung 820, GEOSTECH, PUSPIPTEK, Kota Tangerang Selatan \\ e-mail: bondan.fiqi@bppt.go.id
}

\begin{abstract}
Landslides are disaster events that often occur in the area of Cililin Village, Cililin District, West Bandung Regency, which causes negative impacts such as loss of lives, infrastructure damage, stagnant economy, declining land prices in the local area and psychological trauma to the survivors. Landslide disasters can occur anywhere and anytime, but can be identified using lanslide Early Warning System (EWS). Landslide EWS require a display to display monitoring data to the stakeholders related to landslides disaster in the form of system information application. This web-based landslide disaster system information (Si-Benar) application is designed using several stages of design, that includes diagram design, display design, using PHP programming language, MySQL database and displaying sensoric data from landslide EWS hardware with responsive display. The web-based landslide disaster information system (Si-Benar) is a solution to provide factual information regarding the data used as monitoring and evaluation material on potential landslides disaster in the Cililin Village area, Cililin District, West Bandung Regency.
\end{abstract}

Keywords: landslide, early warning system (EWS), information system, web

\begin{abstract}
ABSTRAK
Tanah longsor merupakan peristiwa kebencanaan yang kerap terjadi di wilayah Desa Cililin, Kecamatan Cililin, Kabupaten Bandung Barat, yang memiliki dampak negatif diantaranya adalah jatuhnya korban jiwa, kerugian rusaknya insfrastruktur, perekonomian yang tersendat, menurunnya harga tanah di daerah setempat serta trauma psikis bagi para korban selamat sehingga menimbulkan berbagai gangguan kejiwaan. Bencana tanah longsor dapat terjadi dimana dan kapan saja, namun dapat diidentifikasi lebih dini menggunakan sistem peringatan dini tanah longsor. EWS tanah longsor memerlukan suatu tampilan untuk menampilkan data-data monitoring kepada stakeholder yang berkaitan dengan bencana tanah longsor berupa sebuah aplikasi sistem informasi. Aplikasi sistem informasi bencana tanah longsor (Si-Benar) berbasis web ini dirancang menggunakan beberapa tahapan perancangan desain diagram, desain tampilan, menggunakan bahasa pemrograman PHP, basis data MySQL dan menampilkan datadata sensor dari hardware EWS tanah longsor dengan tampilan responsif. Sistem informasi bencana tanah longsor (Si-Benar) berbasis web merupakan solusi untuk memberikan informasi faktual mengenai data-data yang digunakan sebagai bahan monitoring dan evaluasi mengenai potensi bencana tanah longsor di wilayah Desa Cililin, Kecamatan Cililin, Kabupaten Bandung Barat.
\end{abstract}

Kata kunci: tanah longsor, sistem peringatan dini, sistem informasi, web 


\section{PENDAHULUAN}

\subsection{Latar Belakang}

Tanah longsor atau sering disebut gerakan tanah adalah suatu peristiwa geologi yang terjadi karena pergerakan masa batuan atau tanah dengan berbagai tipe dan jenis. Secara umum kejadian longsor disebabkan oleh dua faktor yaitu faktor pendorong dan faktor pemicu. Faktor pendorong adalah faktor-faktor yang mempengaruhi kondisi material sendiri, sedangkan faktor pemicu adalah faktor yang menyebabkan bergeraknya material tersebut (Naryanto, 2016).

Berbagai dampak negatif dari terjadinya bencana tanah longsor antara lain adalah jatuhnya korban jiwa, kerugian akibat rusaknya insfrastruktur, perekonomian yang tersendat, menurunnya harga tanah di daerah setempat serta trauma psikis bagi para korban selamat sehingga menimbulkan berbagai gangguan kejiwaan baik ringan maupun berat.

Kecamatan Cililin, Kabupaten Bandung Barat merupakan kawasan rawan terjadinya bencana tanah longsor. Lokasi geografis Desa Cililin, Kecamatan Cililin terletak pada koordinat $107^{\circ} 27^{\prime} 32.7^{\prime \prime} B T$ dan $6^{\circ} 56^{\prime}$ 51,2"LS, dengan luas wilayah $78 \mathrm{~km}^{2}$ dan berpenduduk lebih dari 89.966 jiwa. Terdapat 27.935 infrastruktur bangunan dan jumlah persebaran penduduk kurang lebih $1.157 \mathrm{jiwa} / \mathrm{km}^{2}$ (BPS Kabupaten Bandung Barat, 2016). Terdiri dari beberapa desa, yaitu Batulayang, Bongas, Budiharja, Cililin, Karanganyar, Karangtanjung, Karyamukti, Kidangpananjung, Mukapayung, Nanggerang, dan Rancapanggung.

Pada tahun 2014 wilayah Desa Cililin, Kecamatan Cililin, Kabupaten Bandung Barat sempat mengalami bencana tanah longsor, dimana longsor tersebut menimbun rumah yang menyebabkan satu orang korban jiwa meninggal di tempat dan satu orang luka berat setelah petugas bekerja selama 2 jam menyelamatkan korban. Dampak longsor satu rumah rusak berat dan 4 rumah terancam longsor sehingga penghuninya diungsikan untuk mengantisipasi longsor susulan (PVMBG, 2017).

Wilayah di Kecamatan Cililin saat berpotensi mengalami tanah longsor apabila memasuki musim penghujan, karena lokasinya yang berbukit-bukit dengan struktur tanah yang rawan bergerak apabila air tersebut menembus sampai tanah kedap air yang berperan sebagai bidang gelincir, maka tanah menjadi licin dan tanah pelapukan di atasnya akan bergerak mengikuti lereng dan keluar lereng atau yang biasa disebut tanah longsor.
Beberapa bulan lagi Indonesia akan memasuki musim penghujan, dimana ketika intensitas hujan yang tinggi menyebabkan debit air pada struktur tanah yang melebihi ambang batas akan menyebabkan tanah longsor. Ketika bencana tanah longsor tidak dapat dideteksi lebih dini maka akan menyebabkan lebih besarnya korban jiwa dan infrastruktur. Dampak dari resiko bencana tanah longsor dapat diminimalisir dengan pembuatan sistem informasi mengenai data yang dihimpun secara berkala dari sebuah Early Warning System (EWS) tanah longsor yang dapat diakses kapanpun dimanapun, sebagai bahan monitoring, pengkajian dan evaluasi pra kejadian, saat dan pasca kejadian kebencanaan tanah longsor yang terjadi di Desa Cililin, Kecamatan Cililin, Kabupaten Bandung Barat.

\subsection{Maksud dan Tujuan}

Tujuan dari kajian ini adalah membuat sistem informasi bencana tanah longsor (SiBenar) berbasis web yang dapat memberikan informasi faktual mengenai data-data yang digunakan sebagai bahan monitoring dan evaluasi mengenai potensi bencana tanah longsor di wilayah Desa Cililin, Kecamatan Cililin, Kabupaten Bandung Barat

\section{METODOLOGI PENELITIAN}

\subsection{Lokasi Tujuan Pembuatan Aplikasi}

Lokasi kajian berada di wilayah yang akan diimplementasikan landslide early warning system (EWS) di kawasan rawan longsor di Desa Cililin, Kecamatan Cililin, Kabupaten Bandung Barat, Propinsi Jawa Barat.

\subsection{Lokasi Tujuan Pembuatan Aplikasi}

Penelitian ini dilakukan dengan beberapa langkah dan metode sebagai berikut:

a. Melakukan studi pustaka dan literatur baik data, informasi, maupun penelitian sebelumnya melalui penelusuran literatur berupa jurnal, buku atau website.

b. Melakukan survey lapangan.

c. Berkoordinasi dengan tim hardware mengena data-data sensor mana saja yang akan ditampilkan di web.

d. Merancang desain diagram, dan desain tampilan.

e. Merealisasikan desain menjadi sebuah aplikasi berbasis web dengan platform Yii2 yang menerapkan konsep MVC (Model, View, dan Controller) (Winesett, 2012). 


\section{HASIL DAN PEMBAHASAN}

\subsection{Perancangan}

\subsubsection{Deskripsi Sistem}

Sistem Informasi Geografis adalah sistem informasi khusus yang mengelola data yang memiliki informasi spasial (bereferensi keruangan). Atau dalam arti yang lebih sempit, adalah sistem komputer yang memiliki kemampuan untuk membangun, menyimpan, mengelola dan menampilkan informasi berefrensi geografis, misalnya data yang diidentifikasi menurut lokasinya, dalam sebuah database (wikipedia.org, 2018).

EWS (Early Warning System) bencana tanah longsor terdiri dari dua jenis elemen penyusun, yaitu hardware dan software. Software pada alat ini dibagi juga menjadi dua bagian, yaitu software instrumentasi, dan juga software tampilan data informasi. Software instrumentasi diterapkan pada hardware sampai didapatnya data-data yang diperlukan sebagai data monitoring, analisa, dan bahan yang dipakai untuk menentukan keputusan. Data tersebut nantinya di himpun oleh modul induk, untuk dikomunikasikan datanya ke output speaker maupun database monitoring.

Pada penelitian ini akan dibahas mengenai software tampilan data informasi. Sistem informasi bencana tanah longsor (Si-Benar) berbasis web adalah software tampilan data informasi yang digunakan untuk menampilkan output dari data yang dihimpun dari modul induk. Keluaran tersebut berupa tampilan data lewat suatu tampilan aplikasi, atau yang dapat disebut dengan Graphic User Interface (GUI) dalam web. Tampilan GUI monitoring tersebut berisi konten yang mencakup informasi mengenai data-data apa saja yang akan ditampilkan untuk dimonitoring, dianalisa dan dievaluasi oleh pihak stakeholder kebencanaan (BPBD, BNPB, Kecamatan yang beresiko terkena bencana, dan sebagainya).

Aplikasi ini dibuat dengan bahasa pemrograman PHP. Pemrograman PHP merupakan pemrograman yang sangat cocok dikembangkan di lingkungan web, karena bisa diletakkan pada script HTML ataupun sebaliknya. PHP tergolong sebagai bahasa pemrograman yang digunakan untuk membuat web dinamis (Kasman, 2013).

Kelebihan utama yang dimiliki oleh PHP adalah kekonektivitasnya dengan sistem basisdata di dalam web. Pembuatan basisdata sangat erat hubungannya untuk pembuatan web dinamis, dimana basisdata berisi sumber data yang akan ditampilkan pada tampilan web nantinya. Sistem basisdata yang dapat didukung oleh PHP adalah MySQL, Oracle, Sybase, dan PostgreSQL. PHP dapat berjalan di berbagai sistem operasi seperti windows, unix/linux, solaris maupun macintosh. Sebagian besar sintaks PHP mirip dengan bahasa C, Java dan Perl, ditambah beberapa fungsi PHP yang spesifik (Buana, 2013).

Terdapat konten peta lokasi stasiun dalam aplikasi Si-Benar. Peta adalah sebuah dokumen resmi mengenai bentuk sajian / presentasi atau gambaran/miniatur mengenai unsur-unsur fitur spasial yang pada umumnya terdapat di permukaan bumi pada sebuah media bidang datar (Prahasta, 2013).

Tampilan GUI tersebut sederhana yang berisikan peta, grafik dan tabel. Apabila pemakai aplikasi melihat langsung dapat memahami dengan durasi waktu yang relatif singkat. Adapun konten menunya adalah menu login, menu beranda, menu stasiun lews, dan menu logout.

\subsubsection{Penjelasan Desain}

Desain aplikasi Si-Benar menggunakan bahasa pemodelan diagram, dimana bahasa pemodelan diagram tersebut terdapat jenis behavioral diagram, yang digunakan untuk menggambarkan perilaku komponen-komponen yang ada di dalam sistem. Pada jurnal ini desain sistem yang digunakan adalah behavioral diagram dari Sistem Informasi Bencana Tanah Longsor, dimana terdapat model use case diagram dan activity diagram.

\subsubsection{Diagram use case}

Diagram use case menggambarkan fungsifungsi yang ada pada sistem. Diagram ini lebih berfokus pada fitur-fitur sistem dari sudut pandang pihak luar, yang dalam hal ini adalah pengguna aplikasi (Whitten and Lonnie 2007).

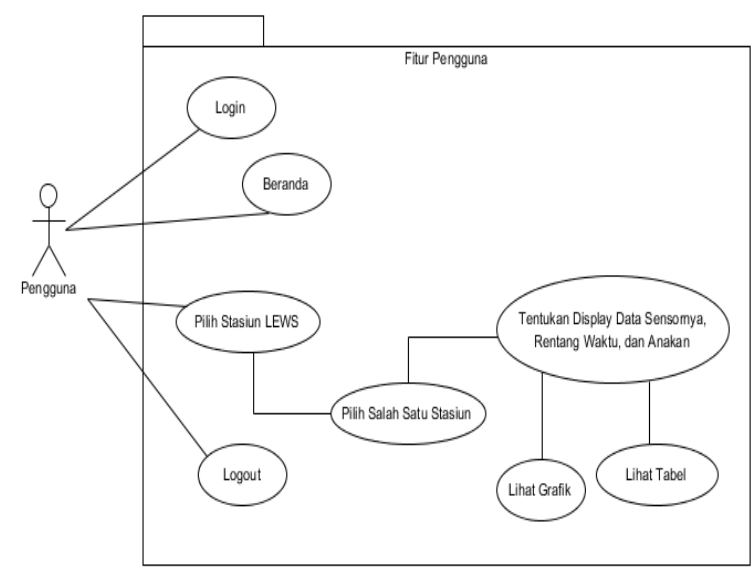

Gambar 1. Diagram Use Case Pengguna

Pada Gambar 1 terdapat beberapa fitur dimana pengguna dapat login, melihat beranda, melihat stasiun lews, dan dapat logout. Semua fitur tersebut dapat diakses apabila pengguna 
sudah masuk menggunakan akunnya masingmasing sebagai pengguna.

\subsubsection{Diagram Aktivitas}

Diagram aktivitas menggambarkan aliran proses suatu perilaku atau aktivitas yang ada di dalam sistem. Di dalam laporan ini, diagram aktivitas sistemnya menggambarkan alur aktivitas sisi pengguna terhadap sistem, atau sebaliknya. Diagram aktifitas ini berisi proses komunikasi lebih mendetail daripada diagram use case, karena diagram activity ini merupakan penjabaran alur-alur yang berada pada diagram use case. Komunikasi yang di maksud adalah komunikasi antara pengguna terhadap sistem. Diagram activity pada aplikasi ini terdiri dari proses login ke sistem, melihat beranda, menambah data stasiun baru, melihat data sebuah stasiun berdasarkan parameter waktu, dan logout dari sistem. Berikut ini merupakan tampilan diagram-diagram aktifitas yang ada pada aplikasi Si-Benar.

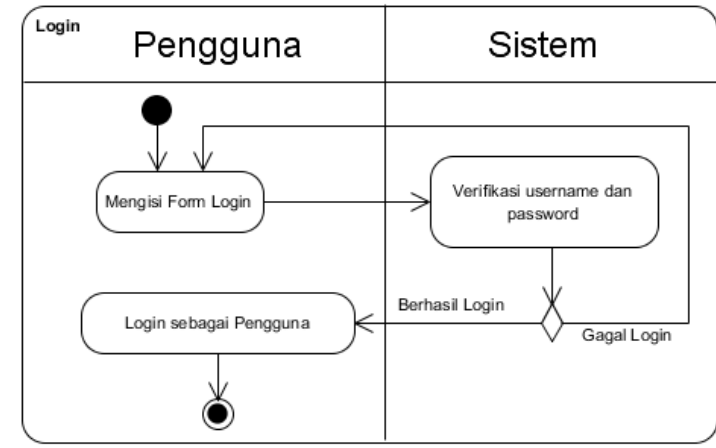

Gambar 2. Diagram Aktivitas Login

Pada Gambar 2, aktivitas ini diawali dengan pengguna mengisi form login dengan username dan password. Kemudian sistem memverifikasi apakah username dan password yang dimasukkan sudah benar atau belum, apabila belum, maka aplikasi akan menampilkan menu login kembali, namun apabila username dan password yang dimasukkan sesuai, maka sistem akan menampilkan halaman beranda.

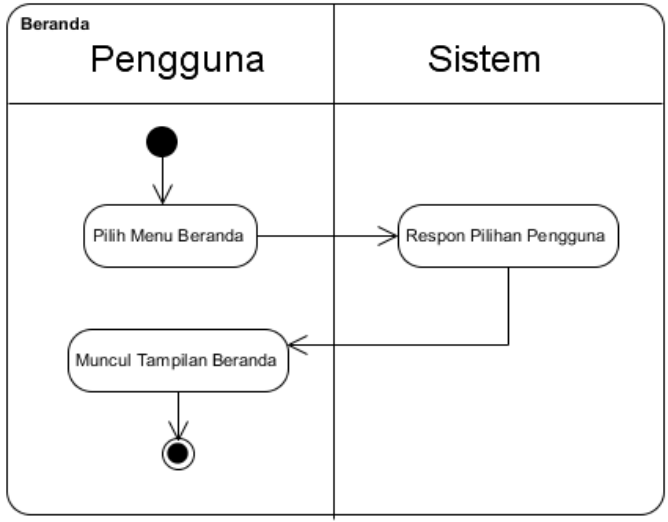

Gambar 3. Diagram Aktivitas Beranda

Pada Gambar 3, aktivitas ini diawali dengan pengguna memilih menu pengguna, dimana sistem langsung menanggapi dengan menampilkan tampilan halaman beranda, yang berisi infografis yang menjelaskan alur pembuatan dan kerja dari EWS (Early Warning System) bencana tanah longsor yang ditempatkan di Desa Cililin, Kecamatan Cililin, Kabupaten Bandung Barat.

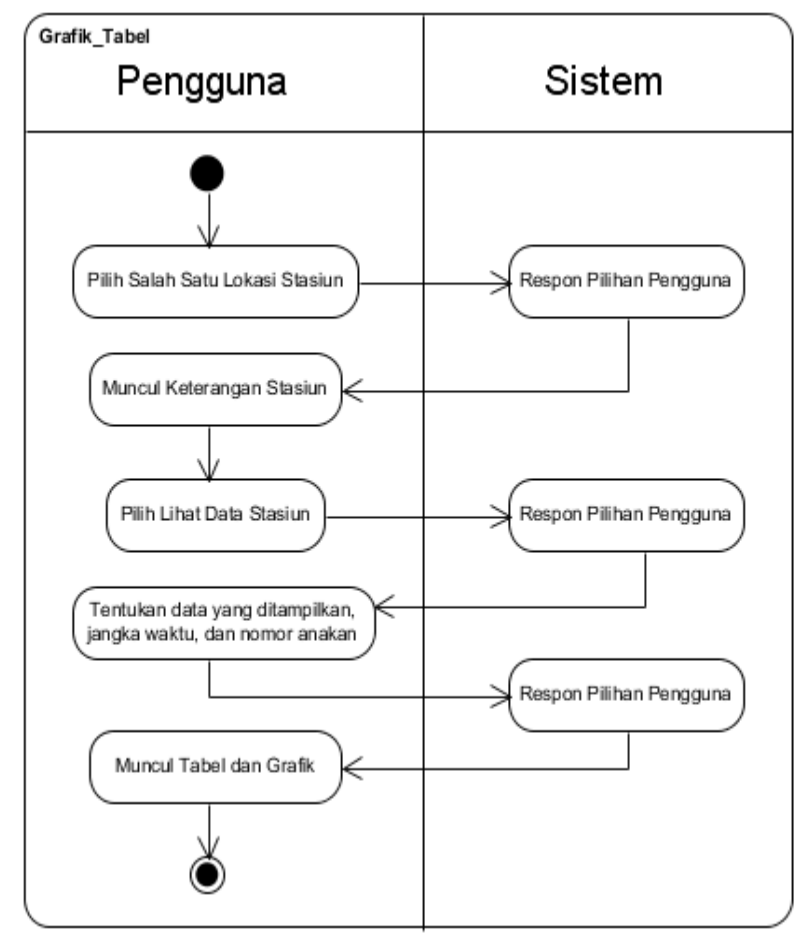

Gambar 4. Diagram Grafik Dan Tabel

Pada gambar 4, aktivitas ini diawali dengan pengguna memilih salah satu lokasi stasiun, kemudian pengguna menentukan rentang waktu/durasi waktu, dan data sensor mana yang akan dilihat Kemudian sensor akan menampilkan data sensor tersebut dalam bentuk visual tabel dan grafik. 


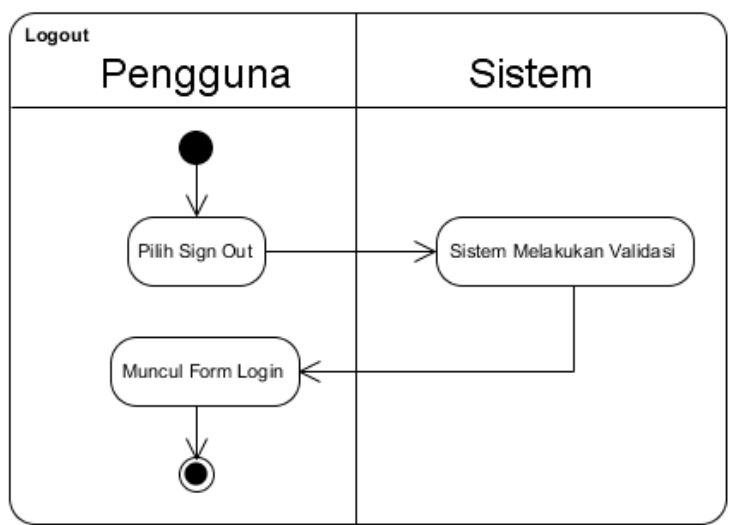

Gambar 5. Diagram Logout

Pada Gambar 5, aktivitas ini digunakan pengguna untuk keluar dari aplikasi, dimana pengguna memilih log out supaya akunnya dapat keluar dari aplikasi tersebut.

\subsection{Desain Tampilan}

Desain tampilan aplikasi dirancang sebagai patokan realisasi aplikasi Sistem Informasi Bencana Tanah Longsor (Si-Benar). Visualisasi tersebut membantu menentukan detail tampilan yang dibutuhkan. Pada aplikasi ini terdapat 3 tampilan utama, yaitu tampilan halaman login, halaman beranda, dan halaman stasiun lews. Berikut ini adalah desain tampilan aplikasi tersebut.

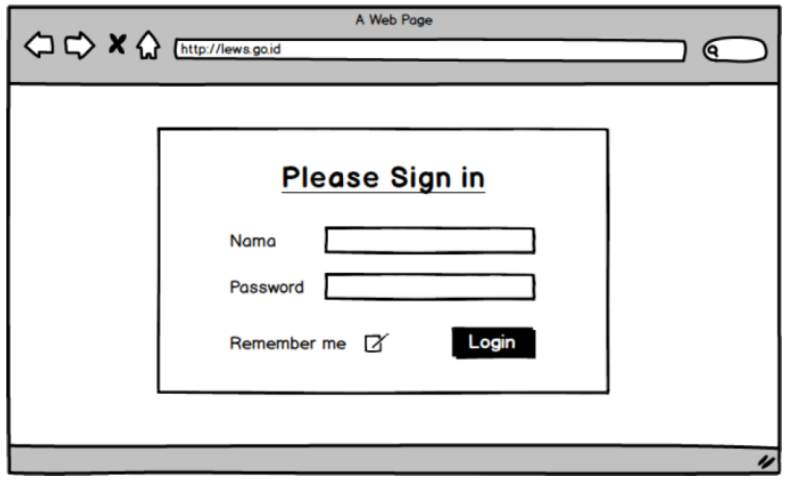

Gambar 6. Desain Tampilan Login

Gambar 6 merupakan desain tampilan login dari aplikasi Si-Benar. Didesain sesederhana mungkin supaya mudah diaplikasikan oleh pengguna aplikasi.

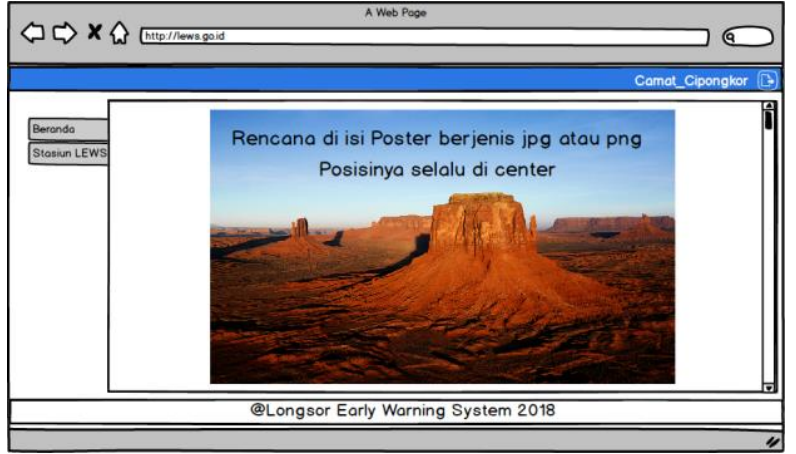

Gambar 7. Desain Tampilan Beranda

Gambar 7 merupakan desain tampilan beranda dari aplikasi Si-Benar. Didesain untuk menampilkan informasi dari pembuatan LEWS (landslide early warning system) atau peringatan dini bencana tanah longsor tersebut dalam bentuk infografis. Infografis dipilih supaya mempermudah pemahaman mengenai informasi pembuatan lews tersebut, hanya dalam waktu yang cukup singkat.

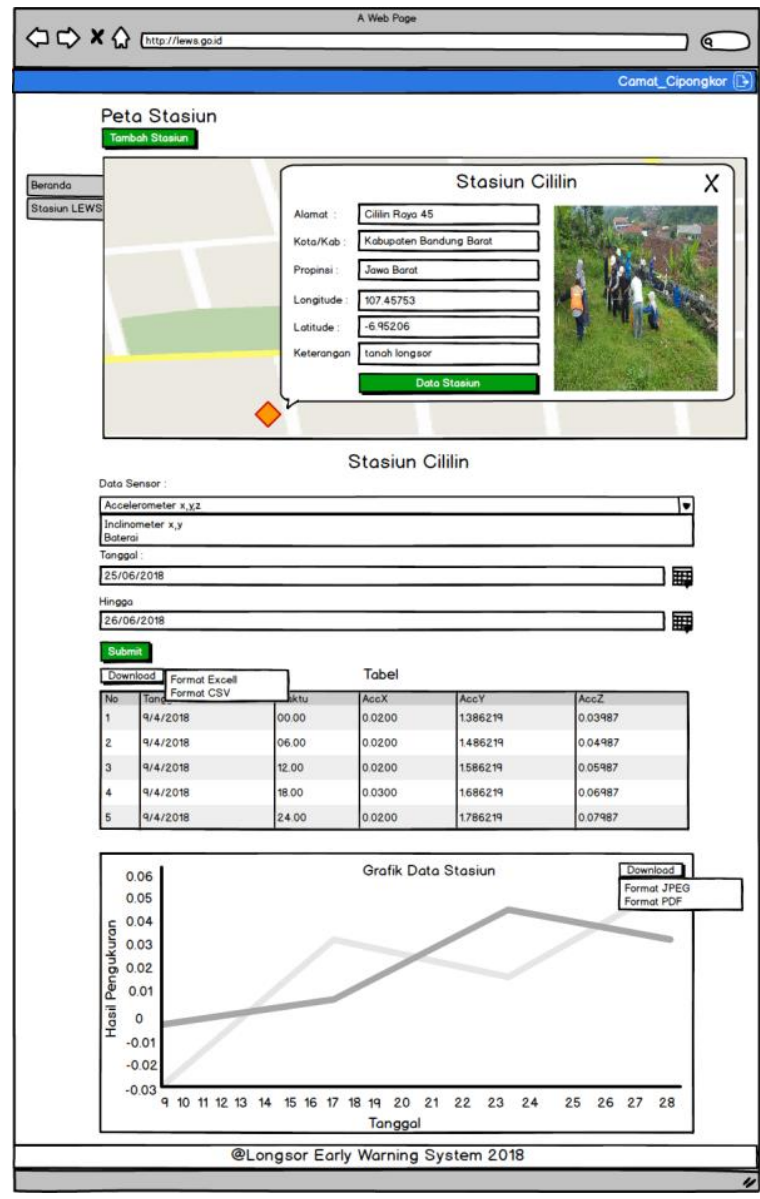

Gambar 8. Desain Tampilan Stasiun LEWS

Gambar 8 merupakan desain tampilan stasiun lews dari aplikasi Si-Benar. Didesain untuk menampilkan tampilkan lokasi stasiun yang data sensor yang akan dilihat dalam bentuk visual tabel maupun grafik, namun 
pengguna harus menentukan jangka waktu data akan dilihat terlebih dahulu. Filter yang digunakan untuk menentukan jangka waktu tersebut diharapkan supaya dapat mempercepat tampilan, karena tidak semua data ditampilkan.

\subsection{Implementasi}

\subsubsection{Basis Data}

Basis data merupakan tempat menampung hasil olahan data-data sensor dari hardware yang berada di lapangan. Basis data dibuat menggunakan My SQL yang sangat support untuk mengelola database dengan jumlah yang cukup besar, gratis dan pengembangan aplikasi menggunakan PHP (Kadir, 2010). Berikut ini merupakan tampilan basis data yang digunakan dalam aplikasi Si-Benar.

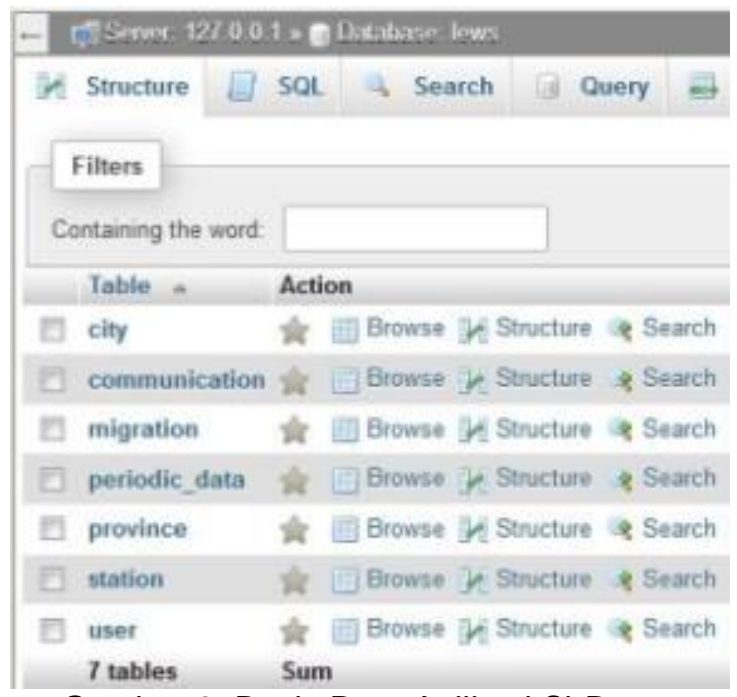

Gambar 9. Basis Data Aplikasi Si-Benar

Gambar 9 merupakan basis data dari $\mathrm{Si}$ Benar. Basis data tersebut terdiri dari beberapa tabel penting, diantaranya station, perodic_data, dan user. Tabel station berisi data stasiun mana saja yang terdaftar pada aplikasi Si-Benar, lokasi koordinat station lews, dan keterangan mengenai stasiun-stasiun tersebut. Tabel perodic_data berisi data-data sensor, diantaranya data waktu, data sensor accelerometer $\mathrm{x}$, data sensor accelerometer $\mathrm{y}$, data sensor accelerometer $z$, data sensor Inclino x, data sensor Inclino y, data sensor soil moisture, data sensor water level, data sensor curah hujan (Arr), dan baterai. Tabel user berisi akun siapa saja yang dapat login/memasuki aplikasi Si-Benar.

\subsubsection{Implementasi Aplikasi}

Implementasi aplikasi ini merupakan realisasi dari desain rancangan aplikasi menggunakan bahasa pemrograman PHP dengan framework Yii2. Berikut ini merupakan hasil implementasi aplikasi tersebut.

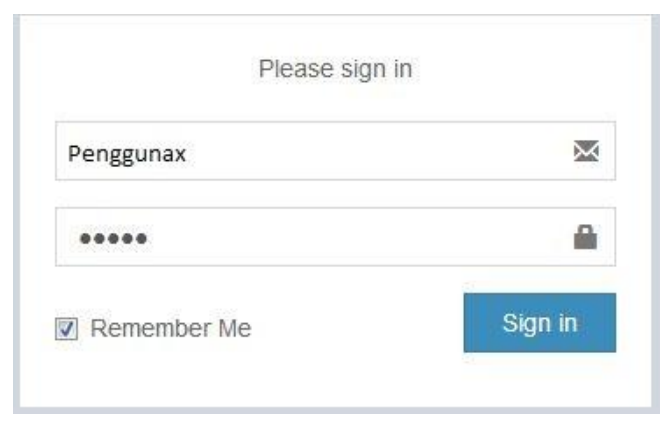

Gambar 10. Tampilan Login

Gambar 10 merupakan tampilan login dari aplikasi Si-Benar. Pengguna harus memasukkan username dan password dari masing-masing akunnya untuk dapat login ke dalam aplikasi.

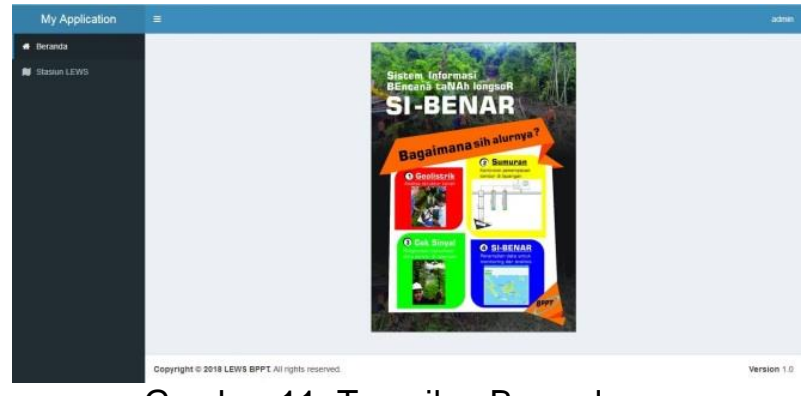

Gambar 11. Tampilan Beranda

Gambar 11 merupakan tampilan beranda dari aplikasi Si-Benar. Setelah pengguna berhasil login menggunakan akunnya masingmasing, maka pengguna dapat melihat tampilan beranda aplikasi ini. Beranda ini berisi informasi dari pembuatan LEWS atau peringatan dini bencana tanah longsor tersebut dalam bentuk infografis. Infografis dipilih supaya mempermudah pemahaman mengenai informasi pembuatan lews tersebut, hanya dalam waktu yang cukup singkat. 


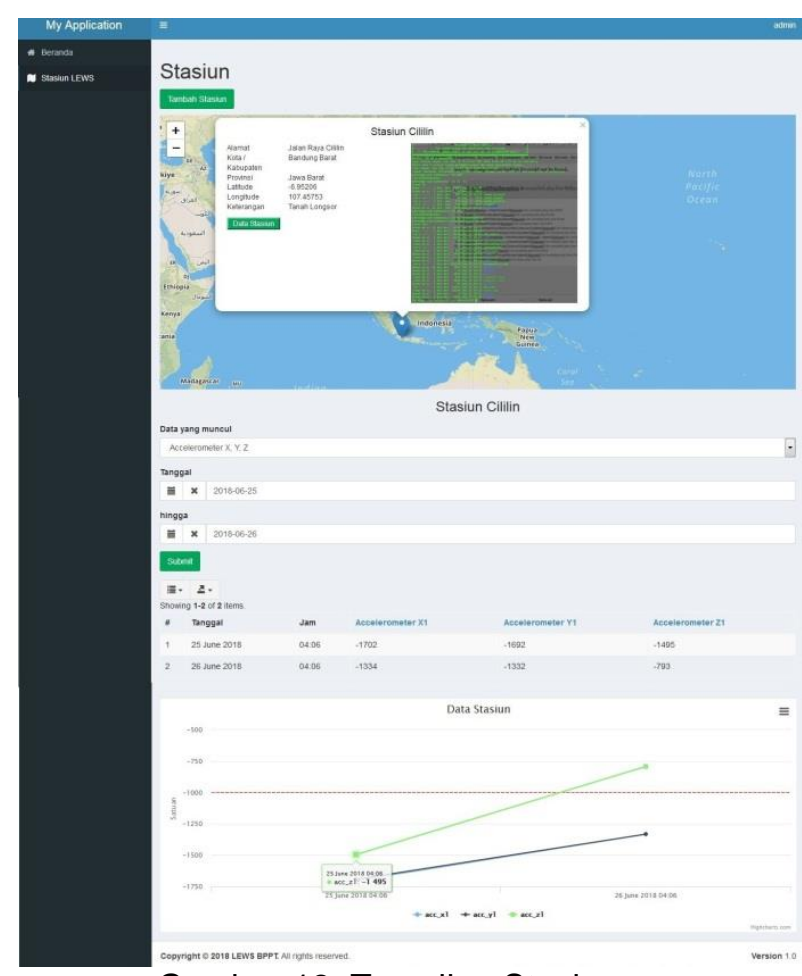

Gambar 12. Tampilan Stasiun

Gambar 12 merupakan tampilan stasiun lews dari aplikasi Si-Benar. Didesain untuk menampilkan tampilkan lokasi stasiun yang data sensor yang akan dilihat. Data tersebut akan muncul ketika ditentukan nilai-nilai filter tanggal, dan sensor apa saja yang akan dimunculkan. Filter tersebut meminimalisir beban load penampilan data ketika awal penampilan tampilan halaman stasiun lews, karena hanya data-data tertentu saja dan dalam kurun waktu tertentu yang akan ditampilkan.

Data-data tersebut dapat digunakan untuk memonitoring dan evaluasi terhadap pengurangan resiko bencana tanah longsor pada daerah berpotensi terkena bencana tanah longsor, seperti wilayah Desa Cililin, Kecamatan Cililin, Kabupaten Bandung Barat. Harapannya supaya meminimalisir besarnya kerugian korban jiwa dan harta akibat bencana tanah longsor, karena dapat dideteksi lebih awal.

\section{KESIMPULAN DAN SARAN}

Aplikasi sistem informasi bencana tanah longsor (Si-Benar) berbasis web ini merupakan solusi untuk memberikan informasi faktual mengenai data-data yang berhubungan dengan potensi bencana tanah longsor di wilayah Desa Cililin, Kecamatan Cililin, Kabupaten Bandung Barat. Diharapkan dengan adanya aplikasi ini, monitoring dan evaluasi terhadap pengurangan resiko bencana tanah longsor pada daerah tersebut dapat berjalan dengan baik dan dapat meminimalisir besarnya kerugian korban jiwa dan harta akibat bencana tanah longsor, karena potensi terjadinya bencana tanah longsor dapat dideteksi lebih awal.

Sebaiknya untuk kedepannya aplikasi ini diimplementasikan di seluruh wilayah berpotensi terkena bencana tanah longsor yang tersebar di seluruh Indonesia, supaya dapat meminimalisir besarnya kerugian korban jiwa dan harta akibat bencana tanah longsor, karena dapat dilakukan monitoring dan evaluasi dimanapun dan kapanpun, selama terhubung dengan jaringan internet untuk mengakses aplikasi Si-Benar ini.

\section{PERSANTUNAN}

Ucapan terima kasih yang sebesarbesarnya penulis sampaikan ke Bapak Heru Sri Naryanto dan Ibu Dyah Nursita Utami, yang telah banyak membantu dalam diskusi, bimbingan serta arahan dalam penyelesaian penyusunan jurnal ini.

\section{DAFTAR PUSTAKA}

BPS Kabupaten Bandung Barat. 2016. Kabupaten Bandung Barat dalam Angka.

Buana, I Komang Setia. 2013. Jago pemrograman PHP, Dunia Komputer, Jakarta.

Kadir, Abdul. 2010. Mudah Mempelajari Database MySQL, Andi, Yogyakarta.

Kasman, Ahmad Dharma. 2013. Kolaborasi Dahsyat Android dengan PHP dan MySQL, Lokomedia, Yogyakarta.

Naryanto, H.S. 2018. Kajian Peta Bahaya Tanah Longsor di Kabupaten Banggai Laut, Provinsi Sulawesi Tengah, Jurnal Alami PTRRB-BPPT vol 2 no 1, Jakarta.

Prahasta, Eddy. 2013. Cara Mendapatkan dan Mengelola Peta-Peta Dijital Penting dan Gratis di Jaringan Internet, Informatika Bandung, Bandung.

PVMBG, 2017, Laporan Singkat Pemeriksaan Gerakan Tanah di Desa Cililin Kecamatan Cililin, Kabupaten Bandung Barat, Provinsi Jawa Barat. [terhubung berkala]. http://www.vsi.esdm.go.id/index.php/gerakan -tanah laporan-singkat-pemeriksaangerakan-tanah-di-desa-cililin-kecamatancililin-kabupaten-bandung-barat-provinsijawa-barat. [1 1 September 2018]. 
Whitten, Jefrrey and Lonnie D. Bentley. 2007.

Systems Analysis and Desain Methods,

McGraw-Hill, New york.

Winesett, Jeffrey. 2012. Web Application

Development with Yii and PHP, Packt

Publishing, Birmingham.

wikipedia.org

--, "sistem informasi geografis". 